\title{
Residents preferences associated with tax amnesty program predisposition
}

\author{
Prasojo, ${ }^{1}$ Lailatis Syarifah ${ }^{2}$
}

1,2Universitas Islam Negeri Sunan Kalijaga Yogyakarta, Indonesia email:prasojo@uin-suka.ac.id

\begin{abstract}
Purpose - The purpose of this study is to determine the motivation of taxpayers to take part in tax amnesty so that it is expected to be able to evaluate the implementation of tax amnesty that has been carried out by the Indonesian government in 2016-2017 and provide empirical evidence on the implementation of the tax amnesty program to support the stick and carrot theory in the implementation of taxation in Indonesia.
\end{abstract}

Method-The methodology used in this research is a case study. Interviews are used to collect data and are supported by secondary data from sites, web, and documents.

Result - The results of this study indicate that the reasons for many taxpayers to join this program were because it is beneficial for the country and avoid the risk of administrative sanctions (fines and interest) as well as audits. The reason for taxpayers who did not participate in this program was because they did not have other assets that had not been reported in the tax return.

Implication - The implication of this study is to determine the motivation of taxpayers to take part in tax amnesty so that it is expected to be able to evaluate the implementation of tax amnesty. At the same time, that has been carried out by the Indonesian government in 2016-2017 and provides empirical evidence on the implementation of the tax amnesty program to reason action and social learning theory in the implementation of taxationin Indonesia.

Originality - This study explores information from regulators (tax officials) and taxpayers, both those who do and who do not participate in tax amnesty, which is rarely done by other researchers.

Keywords: tax amnesty; taxpayer; tax official; declaration of assets 
Prasojo, Lailatis Syarifah

\section{Introduction}

The primary source of state revenue comes from taxes (Warno \& Fahmi, 2020). Therefore, the government has an active role in maximizing the role of

JIAFR | 210 the tax sector, one of which is by launching the Self Assessment System (SAS) as a tax collection system in 1983, but has not shown encouraging results (Damayanti et al., 2015; Diamastuti, 2012).

Even tax revenue in 2017 only grew by $4.08 \%$, lower than the revenue for the same period in 2016, which was $4.25 \%$. The following tax revenue data for 2017 is based on performance reports (Director General of Tax \& Finance, 2017), can see on table 1.

The government continues to strive to increase tax revenues (Bagiada \& Darmayasa, 2016). One way is to launch a Tax Amnesty Program as a form of tax reform. The tax amnesty policy was implemented in Indonesia in 1964 and 1984. At that time, the application of the tax amnesty policy failed because of unsupported facilities and infrastructure (Ragimun, 2016).

Now, the implementation of tax amnesty also experiences several obstacles in the field. One of them is that the taxpayer encounters technical problems related to the return of assets in the form of land or shares that were previously in the name of the nominee (Maula, Saifullah, Nurudin \& Zakiy, 2019). It will have an impact on the issuance of a free certificate (SKB) for taxpayers who follow the tax amnesty program. Besides, there are tax officials who threaten to examine the 2016 tax return and will examine additional assets that have been included in the tax amnesty because they are considered unfair (Sukamdi in ekbis.sindonews.com, 2017).

The Ministry of Communication and Information (2017) states that the tax amnesty receipt data reached IDR 130 trillion, IDR 90.36 trillion from non-Micro Small and Medium Enterprises (UMKM) personal taxpayers. Amounted IDR 7.56 trillion from individual Small and Medium Enterprise's taxpayers, IDR 4.31 trillion from non-MSME corporate taxpayers, and IDR 0.62 trillion from small and medium business taxpayers. While the declaration of assets that reaches IDR 4,813.4 trillion consisted of IDR 3,633.1 
trillion, the declaration of assets in the country and repatriation is IDR 146.6 trillion. When viewed from the tax amnesty participant data, 974 thousand reported the Statement of Assets (SPH) of 921 thousand taxpayers.

Based on the above elaboration, it can be seen that the implementation of the tax amnesty program so far still has some constraints. At the same time, tax amnesty is expected to be able to encourage taxpayers to increase their willingness to pay taxes to increase state revenues from the tax sector. Elimination of sanctions, exemption from inspection and tax investigation, and exemption from the transfer of title is expected to stimulate taxpayers to declare their assets and repatriate their assets from abroad by paying a ransom. In the period of the enactment of the tax amnesty, it is expected that the government will receive income from the ransom fund so that it will increase the state's income (Yuliana, Tarmizi \& Soraya, 2019). Whereas in the long run, taxpayers will find it difficult to hide their income and property because they have entered the tax authority's database.

In the current social and economic context in Indonesia, taxpayers are vulnerable to transfer their assets illegally to other countries such as Singapore (Hidayah dkk, 2020). These violations stem from corruption, illegal trade, and hiding income to avoid taxes. The Indonesian government, through the Ministry of Finance, has seriously highlighted this, thus created the tax amnesty program as a means of eradicating sins. Taxpayers are allowed to declare assets and income that have not been recorded in the annual tax report. This program applies to both domestic and foreign taxpayers to repatriate assets to Indonesia (Megarani, Warno \& Fauzi, 2019).

Table 1. Tax Realization in 2017 Compared to 2016

\begin{tabular}{clrrr}
\hline No & \multicolumn{1}{c}{ Type of Tax } & \multicolumn{1}{c}{$\mathbf{2 0 1 6}$} & \multicolumn{1}{c}{$\mathbf{2 0 1 7}$} & Growth \\
\hline 1 & Non-Oil and Gas Income Tax & $630,113.83$ & $596,582.30$ & $-5.32 \%$ \\
2 & Value-added tax and Value- & $412,213.45$ & $480,721.05$ & $16.62 \%$ \\
& added tax on luxury goods & & & \\
3 & Land and property tax & $19,433.71$ & $16,771.56$ & $-13.74 \%$ \\
4 & Other taxes & $8,104.89$ & $6,738.47$ & $-16.86 \%$ \\
5 & Federal Income Tax & $36,098.56$ & $50,316.70$ & $39.39 \%$ \\
& Total & $1,105,974.44$ & $1,151,130.09$ & $4.08 \%$ \\
\hline
\end{tabular}


Based on this background, this study aimed at examining the Taxpayers' Preferences in the Tax Amnesty Program Participation. The results of this study are expected to provide information on the taxpayers' motivation to take part in tax amnesty. Hence, it is expected to be able to evaluate the implementation of tax amnesty that has been carried out by the Indonesian government in 2016-2017. Those by provide empirical evidence on the implementation of the tax amnesty program to support reason action and social learning theory in implementation of taxation in Indonesia.

\section{Literature Review}

Many developed and developing countries have used tax amnesty as a part of the country's fiscal program (Luitel and Tosun, 2013). Tax amnesty is defined as a one-time program that lasts for a short period that exempts tax obligations (including interest and penalties), civil and criminal penalties from taxes that have not been previously paid by taxpayers, or pay taxes with incorrect tax amounts (Ross, 1986). There are two main objectives of the tax amnesty program. First, it encourages people who do not pay taxes and taxpayers who understate their income to return to the tax register. Second, to improve tax compliance behavior among taxpayers (Ross, 1986).

The theory of reasoned action is widely used to explain the determinants of behavior carried out consciously. This theory hypothesizes that "a person's performance of certain behaviors is determined by behavioral intentions and will be influenced by one's attitudes and subjective norms about the behavior in question". Subjective norms refer to "people's perception that most people think they should or should not take action in question" (Buabeng-Andoh, 2018). When related to the tax amnesty program, it is relevant to the attitude of taxpayers to behave in or not to participate in the tax amnesty program, which is influenced by rationality in considering the benefits and risks obtained if they follow or do not participate in the program.

Social learning theory helps explain behavioral changes resulting from the influence of social actors (Lu, Guo, Lu, \& Gupta, 2017). According to this theory, individuals explore the possible results of behavior from various 
sources of information (for example, observation and communication) before engaging in behavior to predict the outcome and eliminate uncertainty in the decision process. In this tax amnesty case study, social roles such as the socialization of the purpose and benefits of tax amnesty for the state can significantly influence the taxpayers' decision to join the program.

According to Article 1 of Law No. 16 of 2009 on General Provisions and Procedures for Taxation, tax is a mandatory contribution to the state-owned by individuals or entities that are coercive based on the law, with no direct reciprocity and used for the country's needs for the greatest prosperity of the people. Taxpayers are individuals or entities, including taxpayers, tax-cutters, and tax collectors, who have taxation rights and obligations following the provisions of tax legislation (Government of Indonesia, 2008).

Besides, according to Law No. 11 of 2016 on Tax Amnesty, tax amnesty is the abolition of taxes that should be owed, not subject to tax administration sanctions and criminal sanctions in the field of taxation by disclosing assets and paying the ransom as stipulated in the law. The benefits of participating in the tax amnesty program are: (1) Write-off tax that is supposed to be due, the taxpayers do not have to pay an amount of tax as they should do. The tax value that should be owed is written off; (2) Taxpayers participating in this program are exempt from administrative sanctions and taxation sanctions which may ensnare them. (3) Every report submitted will not be subject to a tax audit, and other matters that are usually carried out; (4) Termination of the process of checking the preliminary evidence or investigation. If it is in the process of examination, then this matter will also be terminated with the following of the tax amnesty program. (5) Guaranteed confidential data of tax amnesty, taxpayers participating in the tax amnesty program will be ensured to maintain the confidentiality of their assets; and (6) Exemption from income tax for the return of additional assets (Government of Indonesia, 2016).

Empirical studies have discussed a lot about tax amnesty that affects tax collection during tax amnesty implementation and direct benefits from participating in the tax amnesty program. Alm and Rath (2003) researched taxpayer perception regarding the quality of tax authorities to taxpayer 
compliance with financial conditions and taxpayer risk preferences as a moderating variable in Nigeria with 332 respondents. The results showed that taxpayer perception of tax service quality significantly and positively affected personal taxpayer compliance. In contrast, taxpayer financial condition as the moderating variable had a positive but not significant effect on the relationship between the taxpayer's perception of the quality of tax authorities and personal taxpayer compliance. Risk preference is also a moderating variable that has a negative and not significant effect on the relationship between perceptions about the quality of financial services and personal taxpayer compliance. Besides, the combination of financial conditions and taxpayer risk preferences in moderating the relationship between perceptions about the quality of financial services and personal taxpayer compliance has a positive and significant effect (Alabede, Ariffin, \& Idris, 2011). Awareness of paying taxes has a positive effect on the willingness to pay taxes; the quality of service has a significant effect on the willingness to pay taxes (Irfansyah, Bawono \& Suparlinah, 2020).

In contrast, the taxpayer's knowledge and understanding of tax regulations do not affect the willingness to pay taxes (Hardiningsih, P. and Yulianawati, 2011). The implementation of tax amnesty in Indonesia has the opportunity to be successfully implemented, which has also been successfully implemented in several other countries. However, the government and the House of Representatives must immediately complete the Draft Law and disseminate regulations to the public to increase tax revenue (Alberto, 2016).

\section{Research Methods}

This study explored the taxpayers' preferences in participating in the tax amnesty program and preparation, implementation after the program takes place, and find obstacles from the program implementer (tax employee) side. This program ran from July 2016-March, 2017. A case study was chosen as the methodology for this study. Case studies are suitable for exploratory research that focuses on taxpayers' preferences as a phenomenon in the context of implementing a tax amnesty program by gathering information 
from various sources. Interviews are used to collect data and are supported by secondary data from sites, web, and documents.

In-depth and structured interviews with taxpayers, that took part in the tax amnesty program or those who did not participate in the tax amnesty program but had adequate knowledge of the tax amnesty program. It was conducted to gather information about the meaning of the tax amnesty, the benefits and risks of joining or not following the program, the benefits of tax amnesty for the country, reasons for joining or not participating in the tax amnesty program, obstacles in reporting tax amnesty and hopes and suggestions after participating in the program. Interviews were also conducted with tax officials to get information about the preparation before the program was implemented, the obstacles faced by taxpayers and the solutions provided, the obstacles faced by tax officials, and what suggestion was given if one day the tax amnesty program is re-implemented.

\section{Results and Discussion}

The data collection process was carried out for ten days in October and November. Eight informants consisted of two taxpayers who took part in tax amnesty, taxpayers who did not participate in tax amnesty but had sufficient knowledge about tax amnesty, and tax officials who were directly involved in implementing the tax amnesty program. The data of the taxpayers or tax officials are not displayed as requested by the research informants. The interviews were conducted with four taxpayer informants to answer the following research questions:

\section{Knowledge of The Implementation of The Tax Amnesty Program}

Concerning the deduction of the first research question, answers to the questions dealing with the implementation of the tax amnesty program were collected from the respondents, as presented in Table 2.

Based on the interview results in table 2, several points can answer the first research question, including: 1) Taxpayers understand this tax amnesty program as a remission program for taxpayers who have not reported their 
tax obligations with the correct data. 2) Taxpayers get information about the tax amnesty program from the internet, TV ads and billboards. 3) In the opinion of taxpayers, the socialization by tax officials is already good, because it is done through informal gatherings and many media including mass media, TV advertisements, billboards, internet, and social media.

\section{Benefits of Following and Risks of Not Following The Tax Amnesty}

Concerning the deduction of the second research question, the answers to the questions dealing with benefits and risk of tax amnesty participation were collected from the respondents as presented in table 3.

Based on the interview results in table 3, several points can answer the second research question, including: 1) Benefits for taxpayers who take part in the tax amnesty program include obtaining a tariff reduction because the rates charged on reported assets are smaller than the applicable tax rates. Taxpayers avoid administrative sanctions (fines and interest) on assets reported in the program tax amnesty and taxpayers who have followed tax amnesty will not be examined, for taxpayers who are being audited, the inspection will be dismissed. 2) According to the taxpayer, the tax amnesty program is voluntary so that taxpayers who do not participate in this program will not be penalized. However, taxpayers who do not take part in this program will be at risk in the future because of the potential for amnesty not included in the tax report data. If an examination is found to be untruthful, administrative sanctions (fines and interest) will be charged following applicable law. 3) The benefits of tax amnesty for the country, according to the respondent, is to be able to increase the potential tax in the future. They were updating the taxpayer data that follows the tax amnesty program by minimizing the state's loss on the untruths of taxes reported by taxpayers who generally hide income or assets and can increase state income with a ransom from tax amnesty participants. 
Table 2. The Results of Interviews About Tax Amnesty Knowledge

\begin{tabular}{l} 
*1: What do you know about the tax amnesty program implemented from July 2016-March \\
2017? \\
R**1: Tax amnesty \\
R2: Tax amnesty \\
R3: Tax amnesty program for taxpayers who do not report their assets as a whole \\
R4: Tax amnesty for taxpayers who have not reported tax data correctly \\
\hline Q2: Name the source of information about the tax amnesty program that you have obtained \\
R1: Internet media \\
R2: Internet and billboards \\
R3: TV, Website \\
R4: Billboards, internet, TV ads \\
\hline Q3: Give your opinion on the tax amnesty program socialization \\
R1: Still not enough \\
R2: Through all mass and electronic media, tax and social media gatherings \\
R3: Socialization is good, intensive \\
R4: Socialization has been carried out on a massive scale through advertisements, billboards, the \\
internet, and social media
\end{tabular}

Note: ${ }^{*} \mathrm{Q}=$ question, ${ }^{* *} \mathrm{R}=$ Respondent

Table 3. The Results of Intenviews About The Benefits And Risks

Q1: What benefits do you get if you take a tax amnesty?
R1: Tax reduction
R2: If the taxpayer has an error with the amount of tax that should be paid, then get a pardon so
that the fines and interest could become smaller
R3: Get a low fine if reporting following the stipulated period
R4: Tax reported in the TA period is free of fines and interest and not checked for the backward tax
period (2017 backward tax year)
Q2: Are there sanctions if the taxpayer does not participate in the tax amnesty?
R1: Yes
R2: Yes, i.e. if a tax non-compliance is found after the tax amnesty, a fine will be subject to the
applicable rules
R3: At that time (2017 to March 2018) it was not yet, but now there is an openness to banking
information so that it will be subject to sanctions
R4: There is no because TA is voluntary, but if you do not follow the TA it will be hazardous to be
examined and if found untruthful will get sanctions according to the applicable Tax Law
Q3: What are the benefits of tax amnesty for the country?
R1: Increase tax potential
R2: Minimize the potential for state losses due to unpaid taxes
R3: Increase state income from taxes
R4: increase state revenue and update the database of taxpayers who follow tax amnesty so that
it has the potential to increase tax revenue in the coming years

Journal of Islamic Accounting and Finance Research - Vol. 2 No. 2 (2020) 
Prasojo, Lailatis Syarifah

\section{Motivation, Constraints, dnd Hopes of Participating in The Tax Amnesty Program}

Concerning the deduction of the third research question, the answers the JIAFR | 218 questions dealing with motivation, constraints, and hopes of participating in the tax amnesty program were collected from the respondents as presented in table 4.

Table 4. The Results of Interviews About Motivations, Obstacles, and Expectations Following The Tax Amnesty

Q1: What factors most moved you to take part in the tax amnesty program?

R1: Elimination of financial penalties and interest

R2: I am not following

R3: Tax compliance

R4: deletion of fines and examinations in the past year

Q2: What obstacles did you encounter when preparing the tax amnesty report?

R1: How to count

R2: I did not make a tax amnesty report

R3: Do not know

R4: There are no obstacles

Q3: Are you having trouble reporting tax amnesty?

R1: No

R2: I am not following the tax amnesty program

R3: Do not know

R4: Fill in the tax amnesty form (too much)

Q4: Your expectation after joining the tax amnesty program

R1: Free of tax penalties

R2: Nothing

R3: More and more people are taking part in tax amnesty

R4: Not checked for backward tax years

Q5: Will the decision not to participate in amnesty affect the country?

R1:Yes

R2: Yes

R3: No

R4:Yes

Q6: Will the decision not to take part in amnesty risk you?

R1: No

R2: No

R3: No

R4: Yes, it is risky in the future 
Based on the interview results in table 4, several points can answer the third research question, including: 1) The most influencing factor for taxpayers to take part in tax amnesty is the elimination of administrative sanctions in the form of fines and interest. Avoidance of examination and factors of compliance with tax laws because taxpayers feel they have not reported tax liabilities correctly, then take advantage of this amnesty momentum to correct mistakes in the past. 2) One of the obstacles faced by taxpayers is when calculating the number of assets and debts recognized in the report on tax amnesty. Researchers tried to explore deeper into the respondents; the difficulty in recognizing this asset is related to ownership rights because some assets have not been carried out behind the name and difficulties in estimating fair prices. At the same time, the obstacle to recognizing the amount of debt is to have to confirm each debt balance to the lender. To a bank or leasing, which requires time and debt to individuals, for example, this relative does not usually have legal proof, making it difficult to make a claim. 3) Taxpayers have difficulty when filling out the tax amnesty form because there are too many data forms to fill out. 4) Taxpayers hope that after participating in the tax amnesty program, they will avoid sanctions for the untruthfulness of tax reporting before filing tax amnesty. Avoid inspection because taxpayers have reported assets and paid ransoms voluntarily and expect many taxpayers to use this program because of many benefits for taxpayers themselves and the state. 5) Taxpayer decisions following the tax amnesty program significantly affect the country like obtaining cash funds from ransoms and raising awareness of taxpayers to correct mistakes. In the long term, the government, through the directorgeneral of taxes, can increase the potential for tax revenue through the taxation database proceeds from tax amnesty. 6) The decision of taxpayers not following tax amnesty carries a risk in the future for taxpayers who have not reported all assets and income in the annual tax return either owned or received from domestic or abroad. Because the development of data technology related to inter-state tax will be accessibly integrated so that it will be difficult to hide income or assets. 
Prasojo, Lailatis Syarifah

\section{Assessment and Suggestions on The Implementation of The Tax Amnesty Program}

Concerning the deduction of the fourth research question, the answers to JIAFR | 220 the questions were collected from respondents. The list of questions and the results of the interview are presented in table 5.

Based on the interview results in table 5, some points can answer the third research question, including: 1) Taxpayers consider that the tax amnesty program implemented by the government in July 2016-March 2017 has been successful as seen from the number of compulsory tax attendees reaching 921,741 taxpayers and the ransom of 130 trillion. 2) Suggestions given by taxpayers to the government (tax authorities) are (a) the tax amnesty program needs to be carried out regularly, for example, every five or ten years, for taxpayers who do not participate in the tax amnesty program, (b) an inspection is immediately conducted so that the annual SPT report can be verified, (c) simplify tax amnesty reporting forms and use of more general language so that the public can understand it.

Table 5. The Results of Interviews About The Assessment and Suggestions for Implementing Tax Amnesty

Q1: In your opinion, the tax amnesty program implemented from July 2017-March 2017 is successful or not? Explain!

R1: Successful

R2: Successful

R3: Pretty successful

R4: Successful. It can be seen from the amount of ransom that goes into the state treasury compared to other countries

Q2: What are your suggestions for the tax amnesty program that ended on March 31, 2017?

R1: Tax penalty-free

R2: Need to be done regularly, for example, every 5 or 10 years

R3: Give a fine up to the specified deadline for those who do not report

R4: Ease of administration due to many obstacles in preparing reports and supporting documents 
Residents preferences associated with ...

\section{Results of Interviews with Tax Officials}

The interviews were conducted with four informants of tax officials. This tax employee was directly involved when the tax amnesty program was carried out, among others, as a research officer, help desk, and customer service. Interviews were conducted to answer the following research questions:

\section{Preparation for The Implementation of The Tax Amnesty Program}

Questions were raised to get answers about the preparation before the tax amnesty was carried out, which consist of socialization, division of tasks in the tax amnesty service, and other preparations. Table 6 presents the questions and answers from four tax employee respondents.

The results of the interview in table 6 can answer research questions about the preparation made by tax officials as implementing tax amnesty programs that many preparations have been made by the Directorate General of Taxes (DGT). Before the tax amnesty is implemented-starting from the socialization, education, identification of taxpayers, division of tasks when serving tax amnesty to preparing the infrastructure.

DGT, along with other government officials, conducted socialization through various media channels. Besides, DGT also identified taxpayers who have the potential to take part in tax amnesty with a unique approach through account representatives (AR) of each taxpayer for example by sending them an invitation for a particular socialization event. It is done to educate taxpayers about the benefits of participating in a tax amnesty and the process of following the program. DGT also cooperates with banks, large customers in individual banks with the approach of marketing banks to follow the tax amnesty program as well as socialization that in the future DGT can access banking customer data above a certain amount. 
Prasojo, Lailatis Syarifah

Table 6. The Results of Interviews About The Preparation of The Tax Amnesty Program

JIAFR | 222

Q1: What programs have been carried out in the process of preparation, implementation, and post-tax amnesty program implemented from July 2016-March 2017?

R1: Large-scale socialization through all media including the government ranks led by the

president

R2: Identification of taxpayers

R3: Socialization, team building, infrastructure, implementation coordination, post-amnesty supervision

R4: Socialization, education, accepting submissions, monitoring tax obligations

$\mathrm{P} 2$ : What is the tax amnesty program socialization?

R1: The most significant information dissemination in the field of taxation

R2: very smooth and get an excellent appreciation from the taxpayer

R3: Simultaneously from the Directorate General of Taxation (DGT) or community initiatives by inviting DGT sources, mass media

R4: Dissemination is carried out thoroughly and gradually, the aim is to attract as many taxpayers as possible to join the amnesty program. One way is to collaborate with banks and other sectors

Q3: During what part are you responsible for the tax amnesty program?

R1: Research officer

R2: Receipt maker

R3: Socialization officer, preparation for implementation, research officer, and helpdesk

R4: Recipient of the application

\section{The Obstacles Faced by Taxpayers and Tax Employees}

Questions were raised to get answers about the obstacles faced both in terms of taxpayers and tax officials. Table 7 presents the questions and answers from four tax employee respondents.

The results of the interview in table 6 can answer questions about obstacles during the implementation of tax amnesty, according to tax officials, are as follows: 1) Constraints experienced by taxpayers according to tax officials who serve the tax amnesty process include the recognition of debt and assets as objects of tax amnesty. According to one tax employee, some taxpayers tend not to want to reveal all the assets that are owned because they are still in the name of someone else. Besides, in determining the fair price, many taxpayers tend to value below the market price, if using the purchase price at the time of purchase which was decades ago certainly would not be under the current fair price. It is found in many private 
taxpayers because the majority of assets revealed are fixed assets, while many taxpayers do not have enough cash to pay ransoms. 2) Many taxpayers are unfamiliar with the terms in the tax amnesty filling form; generally, they do not have a background related to taxes. Some taxpayers also complained about the number of forms that must be filled, and it is different from the standard tax return form that they fill. 3) Taxpayers also experience difficulties in understanding the process of following the tax amnesty program and preparing supporting documents so that it cannot be processed on the same day. It frequently happens because taxpayers do not come when they get an invitation to a socialization event or have not read the flow or the requirements for completeness of documents. However, it can be consulted with each account representative (AR) before taxpayers follow tax amnesty.

\section{Table 7. The Results of Interviews About The Obstacles in Implementing Tax Amnesty}

Q1: What questions or constraints often arise from taxpayers participating in the tax amnesty program?

R1: Related to the recognition of debt and property objects that are subject to Tax Amnesty

R2: Obstacles to filling in the tax amnesty form

R3: Completeness of documents, the prerequisite for taxpayers

R4: Steps to follow the amnesty

Q2: What solution do you provide to taxpayers?

R1: Provide a solution to open data in full, thoroughly. Because sanctions are extensive if caught not all out in the tax amnesty

R2: Assisted by the clerk at the helpdesk desk

R3: Helped to complete the form that can be provided from DGT, the perception of the escalation rules in common to the head office

R4: Explain the stages from receipt of the file to receipt of the statement

Q3: As a tax employee, what obstacles did you face when implementing the tax amnesty program?

R1: The debt treatment which is recognized in the law is different from the taxpayer

R2: The level of taxpayer's knowledge of taxpayer's rights and obligations

R3: There are no obstacles

R4: There are no obstacles 
Prasojo, Lailatis Syarifah

\section{Results of the Tax Amnesty Program}

Questions were asked to get answers about the success of the tax amnesty program and suggestions. Table 8 presents the questions and JIAFR | 224 answers from four tax employee respondents.

The results of the interview in table 8 can answer questions about the results of the implementation of tax amnesty according to tax officials, namely:

The tax amnesty program implemented in July 2016-March 2017 has been successful. It can be seen from the number of taxpayers who took part in the tax amnesty program, the number of assets disclosed and the amount of ransom. The following is a comparison of the results of Indonesia's tax amnesty success (July-28 September 2016) with other countries, can see on table 9.

A suggestion from one tax employee for the implementation of tax amnesty activities is that if the program is carried out again in the next period. It has to be a more detailed and in-depth socialization of the recognition of assets and debts so that all tax officials involved in implementing the tax amnesty program have the same perception. Second, all the rules or technical guidelines for implementation must be prepared before the program starts.

Table 8. The Results of Interviews About The Results of The Implementation of Tax Amnesty

Q1: In your opinion, the tax amnesty program implemented from July 2017-March 2017 is successful or not? Explain!

R1: Successful. Many benefits. It also has a good impact on taxpayers because the facilities for the taxpayer are also excellent so that the taxpayer can restart the business from the 2016 tax year R2: Successful, because taxpayers feel much helped by the existence of this tax amnesty program R3: Successful with the vast amount of information that is spread in the community, ransoms, assets that are revealed

R4: Successful. Attracting the enthusiasm of taxpayers in Indonesia to take part in the amnesty program, making Indonesia one of the countries with the most astounding disclosure of assets, and with an enormous ransom

Q2: What are the suggestions for improvement to the obstacles encountered during the implementation of the tax amnesty?

R1: Socialization related to the recognition of debt is more evident at the beginning, and all 
implementing regulations are issued before the program runs. Because a lot of circulars and letters that come out during activities

R2: There are subjects about tax since elementary school, so early citizens of Indonesia understand the importance of taxes for national development

R3: There is no suggestion

R4: There is no suggestion

Table 8. Data of Declaration and Tax Amnesty Ransom (in trillion IDR)

\begin{tabular}{clrrr}
\hline No & \multicolumn{1}{c}{ Country } & Year & Declaration & \multicolumn{2}{c}{ Ransom } \\
\hline 1 & Indonesia & 2016 & 2,514 & 81.1 \\
2 & Italia & 2009 & 1,179 & 59 \\
3 & Chili & 2015 & 263 & 19.7 \\
4 & Spanyol & 2012 & 202 & 17.7 \\
5 & Afrika Selatan & 2003 & 115 & 2.3 \\
6 & Autralia & 2014 & 66 & 7.9 \\
7 & Irlandia & 1993 & 26 & 4.1 \\
\hline
\end{tabular}

Source: liputan6.com (29 September 2016)

\section{Conclusion}

Based on the discussion above, it can be concluded that the tax amnesty program which was carried out in July 2016-March 2017 has been successfully implemented. However, it did not reach the target set by the government. Nevertheless, the achievement of the Director-General of Taxes has surpassed other countries that have run tax amnesty programs. In practice, the implementation still found several obstacles experienced by both taxpayers and tax officials. It is reasonable because the number of taxpayers who take part in this program is almost one million people and they come from different backgrounds, so it is difficult to make the same understanding of the terms and process flow. It has been anticipated by the readiness and excellent service of tax officer in charge of serving this program so that this obstacle can be overcome. We see that the success of the tax amnesty program launched by the Indonesian government. Not only due to the factor of benefits for taxpayers. However, because of the trust of the Indonesian people in the current government performance through infrastructure development programs that provide many benefits to move the economy. 
This development produces tangible assets and can be enjoyed so that it can indirectly increase public awareness to pay taxes.

Suppose the program is implemented again in the next period. In that case, it is suggested that: (1) the tax amnesty program can be implemented online, in addition to providing convenience in simplifying the form and saving time; (2) taxpayers should take the time to follow the socialization, read or consult directly about the procedure and requirements. They are going to take care of tax amnesty themselves (without the help of consultants) so as not to encounter obstacles when participating in the program.

\section{References}

Alabede, J. O., Ariffin, Z. Z., \& Idris, K. (2011). Individual Taxpayers' Attitude and Compliance Behaviour in Nigeria: The Moderating Role of Financial Condition and Risk Preference. Journal of Accounting and Taxation, 3, 91-104. https://doi.org/10.22164/isea.v5i1.54.

Alberto, Ferry (2016). Pengaruh Kebijakan Pengampunan Pajak (Tax Amnesty) Oleh Pemerintah terhadap Potensi Peningkatan Penerimaan Pajak di Indonesia Tahun 2015. Jurnal Ilmiah Universitas Bakrie, 4(1).

Alm, J., \& Rath, D. M. (2003). Tax Policy Analysis: The Introduction of a Russian Tax Amnesty. Ssrn. https://doi.org/10.2139/ssrn.471321

Bagiada, I. M., \& Darmayasa, I. N. (2016). Tax Amnesty Upaya Membangun Kepatuhan Sukarela. Simposium Nasional Akuntansi Vokasi V, 1-24.

Buabeng-Andoh, C. (2018). Predicting students' intention to adopt mobile learning. Journal of Research in Innovative Teaching \& Learning, JRIT03-2017-0004. https://doi.org/10.1108/JRIT-03-2017-0004

Damayanti, T. W., Sutrisno, T., Subekti, I., \& Baridwan, Z. (2015). The Role of Taxpayer's Perception of the Government and Society to Improve Tax Compliance. Accounting and Finance Research, 4(1). https://doi.org/10.5430/afr.v4n1p180

Diamastuti, E. (2012). Ke (Tidak) Patuhan Wajib Pajak: Potret Self Assessment System. Ekonomi dan Keuangan, 20(80), 280-304.

Direktur Jenderal Pajak, \& Keuangan, K. (2017). Laporan Kinerja Direktorat Jenderal Pajak. 
Hardiningsih, P. dan Yulianawati, N. (2011). Faktor-faktor yang Mempengaruhi Kemauan Membayar Pajak. Dinamika Keuangan dan Perbankan, 3(1), 126-142. https://doi.org/ISSN: 1979-4878.

Hidayah, A. N., Indah, A. N., Yus'atika, W., Shofana, N. U., Maulida, L. A., Zahra, H. A., ... \& Aslamiyah, S. (2020). Kolaborasi Otoritas Pajak Bersama Relawan Pajak Dalam Pemberian Layanan Perpajakan di Kantor Pajak Pratama Jepara. Buletin Pembangunan Berkelanjutan, 4(2), 45-55.

Irfansyah, N., Bawono, I. R., \& Suparlinah, I. (2020). Tax Aggressiveness Affected by Corporate Social Responsiblity, Earnings Management, and Audit Quality.Permana: Jurnal Perpajakan, Manajemen, Dan Akuntansi, 12(2), 196-214.

Kominfo. (2017). No Title. Retrieved September 25, 2018, from https://www.kominfo.go.id/content/detail/9520/realisasi-taxamnesty-deklarasi-rp48134-triliun-dan-repatriasi-rp146triliun/0/berita

Lu, Y., Guo, J. C., Lu, Y., \& Gupta, S. (2017). Nankai Business Review International Article information: The Role of Online Communication in Avoiding the Restrictiveness of Shopping Websites: A Social Learning Theory Perspective.

Maula, H., Saifullah, M., Nurudin, N., \& Zakiy, F. S. (2019). The Influence of Return on Assets, Leverage, Size, and Capital Intensity on Tax Avoidance. AFEBI Accounting Review, 4(01), 50-62.

Megarani, N., Warno, W., \& Fauzi, M. (2019). The effect of tax planning, company value, and leverage on income smoothing practices in companies listed on Jakarta Islamic Index. Journal of Islamic Accounting and Finance Research, 1(1), 139-162. https://doi.org/10.21580/jiafr.2019.1.1.3733.

Pemerintah Indonesia. (2008). Undang-Undang Nomor 16 Tahun 2009 Tentang Penetapan Peraturan Pemerintah Pengganti Undang-Undang Nomor 5 Tahun 2008 tentang Perubahan Keempat atas UndangUndang Nomor 6 Tahun 1983 Tentang Ketentuan Umum dan Tata Cara Perpajakan Menjadi Undang-Undang. Sekretarian Negara. Jakarta.

Pemerintah Indonesia. (2016). Undang-Undang Republik Indonesia Nomor 11 Tahun 2016 tentang Pengampunan Pajak. Jakarta. 
Prasojo, Lailatis Syarifah

Ragimun. (2016). Analisis Implementasi Pengampunan Pajak (Tax Amnesty) di Indonesia. Jakarta: Kementrian Keuangan. Jakarta: Kementerian Keuangan. Retrieved from http://www.kemenkeu.go.id

JIAFR | 228

Ross, B. G. (1986). Federal tax amnesty: reflecting on the states' experiences author(s): Bonnie G . Ross Source: The Tax Lawyer, 40(1) (Fall 1986), pp. 145-184 Published by American Bar Association Stable URL: http://www.jstor.org/stable/20769148 Ac, 40(1), 145-184.

Yuliana, E. S., Tarmizi, T., \& Soraya, S. (2019). Efektivitas Implementasi Pemungutan PBB P2 Kota Pontianak. Eksos, 15(2), 129-136.

Warno, W., \& Fahmi, U. (2020). Pengaruh Tax Avoidance dan Biaya Agensi Terhadap Nilai Perusahaan dengan Kualitas Audit sebagai Variabel Moderasi Pada Perusahaan LQ45. EL MUHASABA: Jurnal Akuntansi (eJournal), 11(2), 188-201. 